\title{
THE EFFECT OF THE INTENSITY OF ESTRUS EXPRESSION ON THE FOLLICULAR DIAMETER AND FERTILITY OF NELLORE COWS MANAGED UNDER A FTAI PROGRAM
}

\section{EFEITO DA INTENSIDADE DA EXPRESSÃO DO ESTRO NO DIÂMETRO FOLICULAR E NA FERTILIDADE DE VACAS NELORE SUBMETIDAS A UM PROGRAMA DE IATF}

\author{
Priscila Assis Ferraz ${ }^{1^{*}}$ \\ Marcus Vinicius Galvão Loiola ${ }^{1}$ \\ Alexandra Soares Rodrigues ${ }^{1}$ \\ Marcos Chalhoub Coelho Lima ${ }^{1}$ \\ Thereza Cristina Borio dos Santos Calmon de Bittencourt ${ }^{1}$ \\ Antonio de Lisboa Ribeiro Filho ${ }^{1}$ \\ 1Universidade Federal da Bahia, Salvador, BA, Brazil \\ *Author for correspondence - prisferraz@gmail.com
}

\begin{abstract}
The aim of this study was to determine the relationship between the intensity of estrus expression on the ovulatory follicle diameter (OFD) and its effect on the conception rate in zebu females managed under a FTAI program. On a random day of the estrous cycle, day 0, 308 Nellore females received an intravaginal progesterone device and $2.0 \mathrm{mg}$ of estradiol benzoate were administered intramuscularly (IM). On day 8, the progesterone device was removed, and $300 \mathrm{IU}$ of equine chorionic gonadotropin, $150 \mu \mathrm{g}$ of d-cloprostenol, and $1.0 \mathrm{mg}$ of estradiol cypionate were administered IM. The animals were then painted with animal marker spray between the sacral tuberosity and the tailhead. On day 10, the animals were categorized into three groups: no estrus expression $(n=78)$, low intensity of estrus expression $(n=66)$ and high intensity of estrus expression $(n=164)$. The OFD was then measured, and artificial insemination (AI) was performed. The results suggest that determining the intensity of estrus expression is a good parameter to identify females with greater follicular diameter and increased fertility in Nellore cows submitted to a FTAI protocol.
\end{abstract}

Keywords: artificial insemination; estrus detection; Nellore.

\section{Resumo}

Este trabalho foi conduzido com o objetivo de verificar a relação da intensidade da expressão do estro sobre o diâmetro do folículo ovulatório e seu impacto sobre a taxa de concepção em fêmeas 
zebuínas submetidas a um programa de IATF. Em um dia aleatório do ciclo estral denominado D0, 308 fêmeas da raça Nelore receberam um dispositivo intravaginal de progesterona e foram administrados 2,0 mg de benzoato de estradiol intramuscular (IM). No D8, retirou-se o dispositivo de progesterona e foram aplicados 300UI de Gonadotrofina coriônica equina, $150 \mu \mathrm{g}$ de dCloprostenol e 1,0 mg de cipionato de estradiol IM. Neste momento, os animais foram pintados com bastão marcador entre a tuberosidade sacral e a inserção da cauda. No D10, os animais foram caracterizados em três grupos: Grupo sem expressão do estro $(n=78)$, Grupo baixa intensidade da expressão do estro $(n=66)$ e Grupo alta intensidade da expressão do estro $(n=164)$. Em seguida, procedeu-se à mensuração do diâmetro do folículo ovulatório e foi realizada a inseminação artificial. Os resultados sugerem que a detecção da intensidade da expressão do estro constitui um bom parâmetro para auxiliar na identificação de fêmeas com maior diâmetro folicular e elevada fertilidade em vacas Nelore submetidas a um protocolo de IATF.

Palavras-chave: detecção do estro; inseminação artificial; Nelore.

Received on September $14^{\text {th }} 2015$

Accepted on October $5^{\text {th }} 2016$

\section{Introduction}

The reproductive efficiency in beef cattle remains characterized by low production and conception rate in spite of the advancement in animal reproduction biotechnologies. Therefore, improved herd genetics and increased production efficiency are necessary to increase the economic return of the beef cattle industry in Brazil ${ }^{(1)}$.

Among the available biotechnologies, artificial insemination (AI) is an important tool to promote genetic improvement and to increase the reproductive and production efficiency of beef cattle ${ }^{(2)}$. However, postpartum anestrus, delayed puberty, and the failure to detect estrus are the main factors that limit the reproductive success of AI programs in Bos taurus indicus (zebu) herds ${ }^{(3)}$. The low efficiency of estrus detection in zebu females is because of the reproductive behavior characteristics of these females, which have a shorter estrus that manifests at night, thereby making it difficult to use this biotechnology in beef cattle herds ${ }^{(4,5)}$.

Thus, various hormonal treatments have been developed to manipulate follicular dynamics and synchronize estrus and ovulation cycles, which enable the use of fixed-time artificial insemination (FTAI) without detecting estrus in cows ${ }^{(6)}$. Despite the evolution of hormonal protocols and the wide use of FTAI, the results must be improved $^{(7)}$.

Studies have been conducted to improve the reproductive and success rates of FTAI programs in beef cows ${ }^{(8)}$. Ovulatory follicle diameter (OFD) is an important indicator of fertility in zebu females subjected to the synchronization protocol of $\mathrm{FTAI}^{(9)}$. However, measuring the follicular diameter at the time of AI requires advanced technology, such as an ultrasound machine and a trained technician $^{(10,11)}$.

Recent studies have shown that the presence of an ovulatory follicle at FTAI in females subjected to a synchronization protocol is related to estrus, increased ovulatory capacity, and a higher 
probability of conception $^{(12)}$. Females in estrus have higher concentrations of estradiol at AI and hence a higher likelihood of conception compared to females that are not in estrus ${ }^{(13)}$.

Recently, auxiliary methods have been developed to increase the efficiency of estrus detection in cows. In this context, animal marker spray can be used as a practical and accessible tool for estrus detection between the removal of the progesterone source (P4) and FTAI, and it is an alternative for improving the efficiency of synchronization protocols for FTAI, thus replacing the more costly methods that are difficult to apply in beef cattle herds ${ }^{(14)}$.

The aim of this study was to evaluate the relationship between the intensity of estrus expression, OFD, and conception rates of zebu females subjected to a synchronization protocol for FTAI using the animal marker spray method to identify the intensity of estrus expression.

\section{Materials and Methods}

The experiment was conducted between September and December 2012 on the API Ranch located in the municipality of Catu at the Recôncavo region of Bahia, Brazil. The region has an average annual rainfall of 1,400 $\mathrm{mm}$ and has a humid tropical climate.

In total, 308 Nellore females (Bos taurus indicus) were included in the study. These animals belonged to the category of parous cows with a mean age of $4.07 \pm 2.34$ years, body condition score of $3.19 \pm 0.42$ (scale from 1 to 5$)^{(15)}$, and postpartum interval of $64.58 \pm 18.42$ days. The animals were maintained on pasture predominantly consisting of Brachiaria decumbens with mineral supplementation and water ad libitum.

Prior to the implementation of the FTAI protocol, the females received a clinical gynecological examination and transrectal ultrasound with a linear transducer at a frequency of $5.0 \mathrm{MHz}$ (Mindray, DP2200vet, São Paulo, Brazil). The cows without reproductive tract abnormalities at the evaluation were considered suitable participants for the experiments.

The females were subjected to the following synchronization protocol: on a random day of the estrous cycle, day 0 (D0), parous cows received a new intravaginal device containing $1.9 \mathrm{~g}$ of progesterone $\left(\mathrm{P}_{4}, \mathrm{CIDR}^{\circledR}\right.$, Pfizer, São Paulo, Brazil). All cows received $2.0 \mathrm{mg}$ of estradiol benzoate (GONADIOL $^{\circledR}$, Tecnopec, São Paulo, Brazil) intramuscularly (IM) with the insertion of the progesterone-releasing intravaginal device. On day 8 , the progesterone-releasing intravaginal device was removed, and 300 IU of equine chorionic gonadotropin (eCG, NOVORMON ${ }^{\circledR}$, MSD Saúde

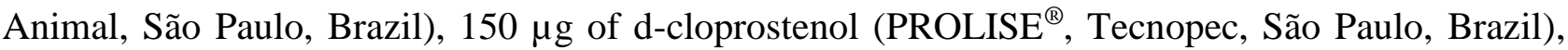
and $1.0 \mathrm{mg}$ of estradiol cypionate $\left(\mathrm{ECP}^{\circledR}\right.$, Pfizer, São Paulo, Brazil) were administered IM. The cows were painted with color chalk (RAIDEX ${ }^{\circledR}, \mathrm{GmbH}$, Dettingen/Erms, Germany) between the sacral tuberosity and the tailhead. The females remained in the same paddock so that the females in estrus could accept mounting but there was only female-to-female interaction, which was noted by the removal of the animal tail chalk.

On day 10, the females were classified into three groups based on estrus expression: the tail chalk that was not removed $(n=78)$ characterizing the non-estrus group; the tail chalk that was partially removed $(n=66)$ characterizing the group expressing low intensity of estrus; and the tail chalk that was completely removed $(n=164)$ characterizing the group expressing high intensity of estrus. 
Furthermore, the OFD was measured by transrectal ultrasound using a linear transducer at a frequency of 5.0 MHz (Mindray, DP2200vet, São Paulo, Brazil). Both ovaries were examined, and the diameter of the largest follicle at this time was identified and measured. The animals were inseminated 48 to $54 \mathrm{~h}$ after removing the progesterone device with doses of cryopreserved semen from five Nellore bulls with known fertility, thawed at $37{ }^{\circ} \mathrm{C}$ for 30 seconds, and distributed homogeneously among the experimental groups. The sperm parameters of the semen doses were within the minimum values established by the Brazilian College of Animal Reproduction ${ }^{(16)}$. In this study, to avoid effects of the insemination technician, the same technician performed all the inseminations.

Pregnancy was diagnosed using a transrectal ultrasound at 35 days post-insemination. The presence of an embryonic vesicle with a viable embryo (heartbeat) was considered a positive pregnancy diagnosis. The conception rate was calculated by dividing the total number of pregnant cows by the number of inseminated cows. All animal interventions began at 08:00 a.m.

Data were analyzed using the Statistical Package for Social Sciences (SPSS version 19), considering a significance level of $5 \%$. The variables studied were ovulatory follicle diameter, intensity of oestrus expression, and response to pregnancy diagnosis after insemination. Therefore, the following sequence of tests was carried out: comparison between experimental groups regarding DFOL and intensity of oestrus expression was performed by Mann-Whitney test due to nonnormality. The conception rate between the experimental groups was compared by applying a frequency dispersion study using the chi-square test $\left(\chi^{2}\right)$.

As for the response variable, pregnancy diagnosis was assumed to present binomial distribution and it was analyzed based on logistic regression methodology. The objective of this analysis was to verify the significance of each variable in explaining the variation in the diagnosis of pregnancy, to quantify the change in the chance of pregnancy for each unit of increase in regression variables and use these variables to predict the probability of pregnancy (Pi). The tested variables were intensity of estrus expression and diameter of the ovulatory follicle. The model adjusted by stepwise method for probability of pregnancy $(\mathrm{Pi})$ was:

$$
P_{i=\frac{\exp \left(\mathrm{y}^{\wedge}\right)}{1+\exp \left(\mathrm{y}^{\wedge}\right)}}
$$

where yij $=-2.25+0.25$ ESTRUS1+0.79 ESTRUS2+0.14 DFOL, Yij = probability of pregnancy, ESTRUS1 = expressing low intensity estrus, ESTRUS2 = expressing high intensity estrus, OFD = Ovulatory follicle diameter. The $2 \mathrm{R} \max$ (which can reach statistical maximum value of 1 ) of the model was $12 \%$.

\section{Results and Discussion}

In this study, the intensity of estrus expression influenced OFD. Comparisons between the group without estrus expression and low intensity of estrus expression showed no significant difference, but the group with a high intensity of estrus expression had a larger OFD ( $p=0.0002)$ than the 
other groups. The average sizes of the OFD among groups are described on Table 1 .

Table 1. Comparison of the ovulatory follicle diameter (OFD) in the different experimental groups of Nellore cows

\begin{tabular}{lcc}
\multicolumn{1}{c}{ Experimental groups } & $\begin{array}{c}\text { Number of } \\
\text { animals (N) }\end{array}$ & $\begin{array}{c}\text { Ovulatory follicle diameter } \\
(\mathbf{O F D})(\mathbf{m m}) \\
\text { Mean } \pm(\mathbf{S})\end{array}$ \\
\hline No estrus expression & 78 & $10.67 \pm 2.91_{\mathrm{a}}$ \\
Low intensity of estrus expression & 66 & $11.81 \pm 3.62 \mathrm{a}$ \\
High intensity of estrus expression & 164 & $13.70 \pm 2.70_{\mathrm{b}}$ \\
\hline Total & 308 & $12.52 \pm 3.24$ \\
\hline
\end{tabular}

1 Different letters $(a, b)$ denote statistical difference $(P<0.05)$ between treatments.

In the present study, the intensity of estrus expression between the removal of the progesterone device and the time of FTAI was an important indicator of increased follicular diameter in Nellore females subjected to a protocol to synchronize ovulation. The results were similar to those reported by other studies on zebu cows ${ }^{(8,17,18)}$. Larger ovulatory follicles at the time of AI have been associated with elevated concentrations of estradiol and consequently a high incidence of estrus expression ${ }^{(19)}$. Similarly, Atkins et al. ${ }^{(20)}$ reported a significant positive correlation between estradiol concentration and follicular diameter.

Based on the results, there were significant differences in the conception rate between the different experimental groups: no estrus expression (32.1\%), low intensity of estrus expression (37.9\%), and high intensity of estrus expression (62.2\%). Comparisons of the conception rates between the groups with no estrus expression and a low intensity of estrus expression showed no significant differences, but the group with a high intensity of estrus expression had a higher conception rate $(\mathrm{p}=0.0001)$ than the other groups (Table 2$)$.

Table 2. Comparison of conception rates in the different experimental groups of Nellore cows

\begin{tabular}{lcc}
\hline \multicolumn{1}{c}{ Experimental groups } & $\begin{array}{c}\text { Number of } \\
\text { animals }(\mathrm{N})\end{array}$ & Conception rate (\%) \\
\hline No estrus expression & 78 & $32.1(25 / 78)_{\mathrm{a}}$ \\
Low intensity of estrus expression & 66 & $37.9(25 / 66)_{\mathrm{a}}$ \\
High intensity of estrus expression & 164 & $62.2(102 / 164)_{\mathrm{b}}$ \\
\hline Total & 308 & $49.4(152 / 308)$ \\
\hline
\end{tabular}

1 Different letters $(a, b)$ denote statistical difference $(P<0.05)$ between treatments.

Therefore, the positive association between the likelihood of conception and estrus expression is potentially related to higher concentrations of estradiol in females expressing estrus ${ }^{(21)}$. These high 
levels of estradiol at insemination seem to favor fertilization by influencing sperm transport ${ }^{(22,23)}$ and promoting positive changes in the uterine environment ${ }^{(24)}$. Under the influence of estrogen, a decrease in uterine $\mathrm{pH}$ is observed. This change in $\mathrm{pH}$ resembles that of seminal plasma regarding $\mathrm{pH}^{(25)}$. Thus, the reduction in uterine $\mathrm{pH}$ leads to a decrease in sperm motility and metabolism, which increases its viability and permanence in the female reproductive tract until ovulation, thus favoring fertilization ${ }^{(26)}$.

According to Perry et al. ${ }^{(11)}$, this improvement in the conception rate of females expressing estrus might have occurred because these females had a higher ovulation rate and better synchronization of ovulation compared to females that did not express estrus. This phenomenon was triggered by the size of the ovulatory follicle at the time of FTAI and by high concentrations of estradiol, promoting a higher rate of conception. Furthermore, Sá Filho et al. ${ }^{(17)}$ reported that estrus following the synchronization protocol can improve the efficiency of FTAI protocols in Nellore cows and can be used as a strategy to improve the use of sexed semen in reproductive programs.

In this study, based on the conception probability according to OFD, it was also possible to estimate the probability of conception for the regressor variable OFD, as seen in Figure 1. These results are similar to those reported by Ribeiro Filho et al. ${ }^{(13)}$, who observed that an increase in OFD led to an increased likelihood of conception. In Nellore females who had OFDs larger than $13.60 \mathrm{~mm}$, the mean estimated likelihood of conception was $78.83 \%$, which was significantly higher than that in females with diameters of up to $11.20 \mathrm{~mm}$ and between 11.20 and $13.60 \mathrm{~mm}, 33.78$ and $59.17 \%$, respectively. Similarly, Borsato et al. ${ }^{(28)}$ studied Bos taurus taurus X Bos taurus indicus heifers and observed a linear increase between conception rate and OFD. These authors observed that animals with ovulatory follicles between 7 and $10 \mathrm{~mm}$ had conception rates of $11.1 \%$, whereas those with 10- to $13-\mathrm{mm}$ follicles had a conception rate of $63.8 \%$, and those with 13 - to $19-\mathrm{mm}$ follicles had a conception rate of $88.2 \%$.

Females with larger follicles have a higher ovulation rate, a larger corpus luteum diameter and, consequently, a higher concentration of progesterone compared to females that have smaller follicles ${ }^{(12)}$. In addition, Vasconcelos et al. ${ }^{(29)}$ reported that the lower progesterone level from females with smaller follicles, can affect the fertility because of insufficient embryonic development and reduced IFN-tau production by the embryo. After ovulation, progesterone plays a fundamental role in endometrial secretion, recognition and maintenance of pregnancy, and embryonic development ${ }^{(30)}$.

Additionally, the logistic regression indicated that on average, females with high and low intensity estrus expression had a 56 and $39 \%$ probability of becoming pregnant, respectively, versus $31 \%$ for females with no estrus expression (Figure 2). 


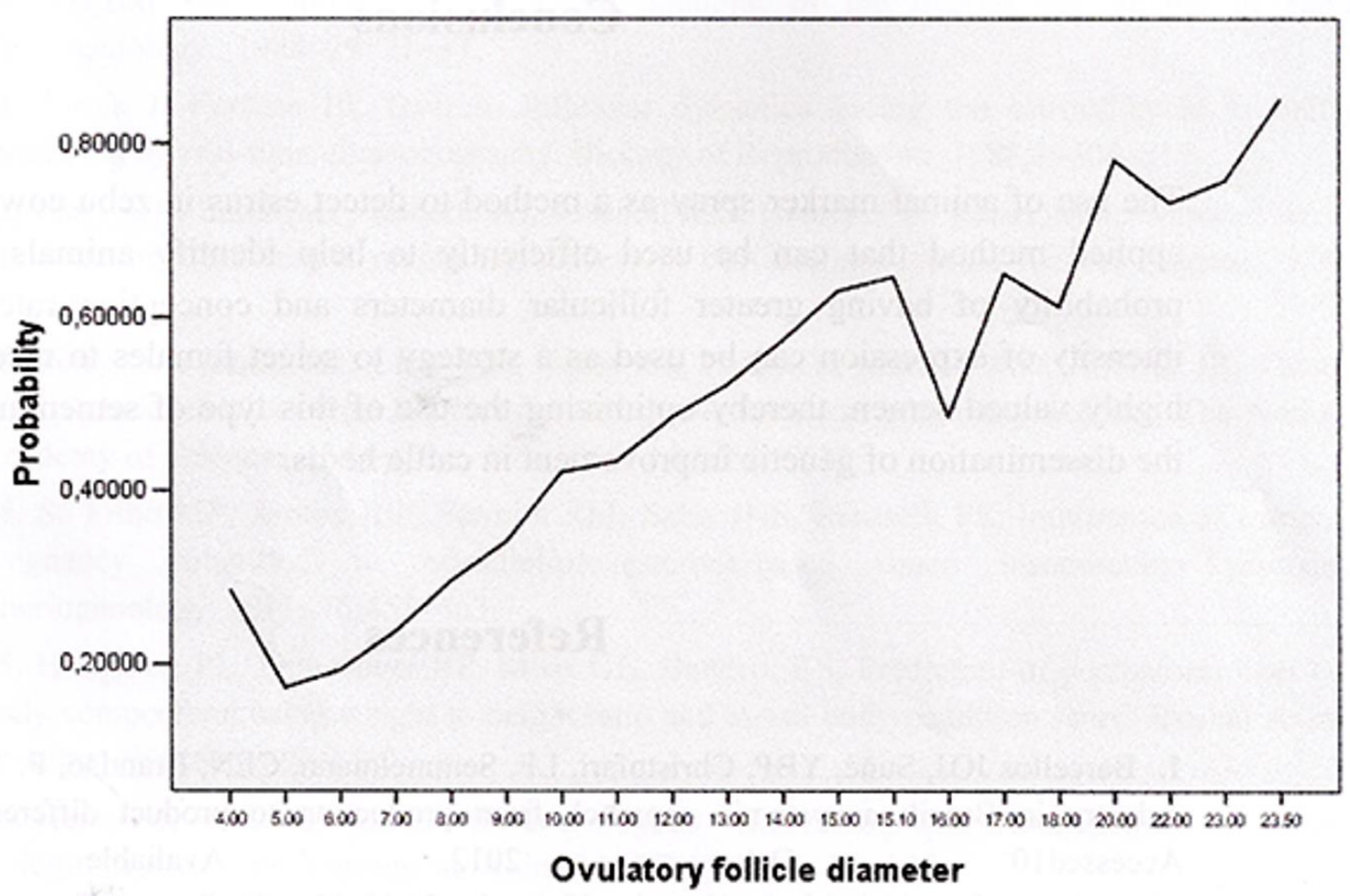

Figure 1. Probability of conception after FTAI in Nellore females relative to the diameter of the largest follicle observed at FTAI (OFD).

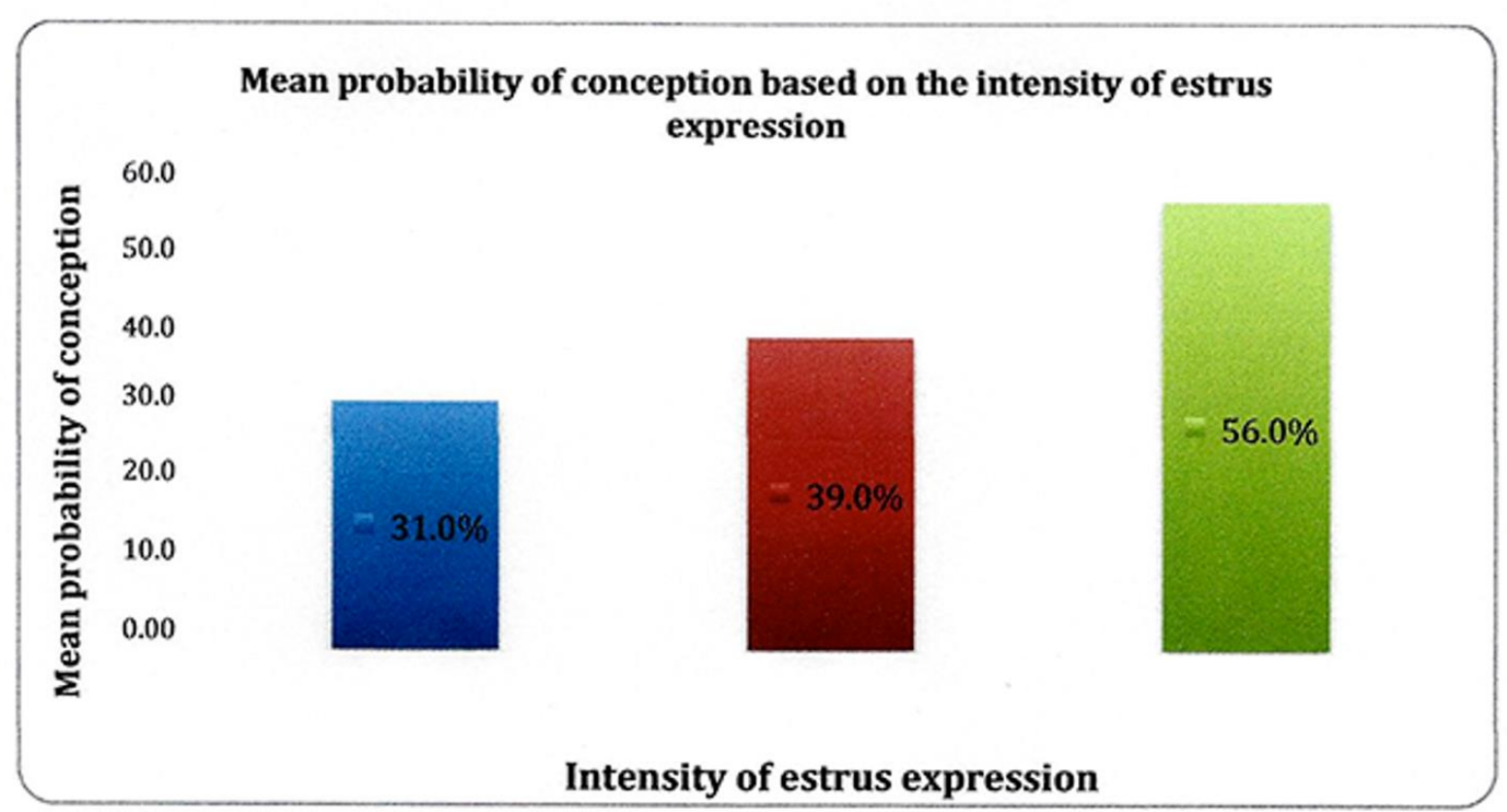

Figure 2. Probability of conception in Nellore females based on the intensity of estrus expression (OFD) 


\section{Conclusions}

The use of animal marker spray as a method to detect estrus in zebu cows is an easily applied method that can be used efficiently to help identify animals with a high probability of having greater follicular diameters and conception rates. Thus, the intensity of expression can be used as a strategy to select females to receive sexed or highly valued semen, thereby optimizing the use of this type of semen and promoting the dissemination of genetic improvement in cattle herds.

\section{References}

1. Barcellos JOJ, Suñé, YBP, Christofari, LF, Semmelmann, CEN, Brandão, F. The beef cattle industry in Brazil: a systemic approach from production to product differentiation 2006. Accessed10 Oct. 2012. Avaliable from: <http://www.fee.tche.br/sitefee/download/jornadas/2/e13-03.pdf>. Portuguese.

2. Inforzatto GR, Santos WRM, Climeni BSO, Dellalibera FL, Filadelpho AL. Using FTAI (Fixed-Time Artificial Insemination) as an alternative in beef cattle reproduction Revista Científica Eletrônica de Medicina Veterinária. 2008;11:1-8.

3. Baruselli PS, Reis EL, Marques MO, Nasser LF, Bó GA. The use of hormonal treatments to improve reproductive performance of anestrous beef cattle in tropical climates. Animal Reproduction Science. 2004;82-83:479-486.

4. Galina CS, Orihuela A, Rubio I. Behavioural trends affecting oestrus detection in Zebu cattle. Animal Reproduction Science. 1996;42:465-470.

5. Pinheiro OL, Barros CM, Figueiredo RA, do Valle ER, Encarnação RO, Padovani CR. Estrous behavior and the estrus-to-ovulation internal in Nelore cattle (Bos indicus) with natural estrus or estrus induced with prostaglandin F2 $\alpha$ or Norgestomet and estradiol valerate. Theriogenology. 1998;49:667-681.

6. Bó GA, Baruselli PS, Martinez MF. Pattern and manipulation of follicular development in Bos indicus cattle. Animal Reproduction Science. 2003;78:307-326.

7. Baruselli PS, Sales JNS, Sala RV, Vieira LM, Sá Filho MF. History, evolution and perspectives of timed artificial insemination programs in Brazil. Animal Reproduction. 2012; 9:139-152.

8. Meneguetti M, Sá Filho OG, Peres RFG, Lamb GC, Vasconcelos JLM. Fixed-timed artificial insemination with estradiol and progesterone for Bos indicus cows I: Basis for development of protocols. Theriogenology. 2009;72: 179-189.

9. Ribeiro Filho AL, Ferraz PA, Rodrigues AS, Bittencourt TCBSC, Loiola MVG, Chalhoub M. Diâmetro do folículo no momento da inseminação artificial em tempo fixo e taxa de concepção em vacas Nelore [Follicle diameter at fixed-time artificial insemination and conception rate in Nellore cows]. Ciência Animal Brasileira. 2013;14 (4):501-507.

10. Pierson RA, Ginther OJ. Ultrasonic imaging of the ovaries and uterus in cattle. Theriogenology. 1988; 29: 21-37.

11. Sirois J, Fortune JE. Ovarian follicular dynamics during the estrous cycle in heifers monitored by realtime ultrasonography. Biology of Reproduction. 1988;39308-317.

12. Perry GA, Smith MF, Roberts AJ, Macneil MD, Greary TW. Relationship between size of the ovulatory follicle and pregnancy success in beef heifers. Journal Animal Science. 2007; 85:684-689.

13. Perry GA, Smith MF, Lucy MC, Green JA, Parks TE, Macneil MD, Andrew JR, Thomas WG. Relationship between follicle size at insemination and pregnancy success. The National Academy of Sciences of the USA, 102. 2005; 14:5268-5273. 
14. Sá Filho MF, Santos JEP, Ferreira RM, Sales JNS, Baruselli PS. Importance of estrus on pregnancy submitted to estradiol/progesterone-based timed insemination protocols. Theriogenology. 2011; 76:455-463. 15. Houghton PL, Lemenager RP, Moss GE, Hendrix KS. Prediction of postpartum beef cow body composition using weight to height ratio and visual body condition score. Journal Animal Science. 1990;68:1428-1437.

16. Henry M, Neves JP. Manual for andrological examinations and animal semen evaluations. Colégio Brasileiro de Reprodução Animal (CBRA). 2013; 3:1-104.

17. Sá Filho MF, Crespilho AM, Santos JEP, Perry GA, Baruselli PS. Ovarian follicle diameter at timed insemination and estrous response influence likelihood of ovulation and pregnancy after estrous synchronization with progesterone or progestin-based protocols in suckled Bos indicus cows. Animal Reproduction Science. 2010;120:23-30

18. Andrade BHA, Ferraz PA, Rodrigues AS, Loiola MVG, Chalhoub M, Ribeiro Filho AL. Eficiência do cipionato de estradiol e do benzoato de estradiol em protocolos de indução da ovulação sobre a dinâmica ovariana e taxa de concepção de fêmeas Nelore inseminadas em diferentes momentos [Efficiency of estradiol cypionate and estradiol benzoate in ovulation inducer protocols on ovarian dynamics and conception rate of Nelore females inseminated at different times]. Archives of Veterinary Science. 2012;17(4):70-82.

19. Sá Filho OG, Meneghetti M, Peres RFG, Lamb GC, Vasconcelos JLM. Fixed-time artificial insemination with estradiol and progesterone for Bos indicus cows II: Strategies and factors affecting fertility. Theriogenology. 2009;72: 210-218.

20. Atkins JA, Smith MF, Wells KJ, Geary TW. Factors affecting preovulatory follicle diameter and ovulation rate after gonadotropin-releasing hormone in postpartum beef cows. Part I: Cycling cows. Journal Animal Science. 2010;88:2300-2310.

21. Roelofs J, López-Gatius F, Hunter RHF, Van Eerdenburg FJCM; Hanzen CH. When is a cow in estrus? Clinical and practical aspects. Theriogenology. 2010;74:327-344.

22. Perry GA, Perry BL. Effect of preovulatory concentrations of estradiol and initiation of standing estrus on uterine pH in beef cows. Domestic Animal Endocrinology. 2008;34:333-338.

23. Hawk HW. Sperm survival and transport in the female reproductive tract. Journal Dairy Science. $1983 ; 77: 2738-2744$.

24. Acott TS, Carr DW. Inhibition of Bovine Spermatozoa by Caudal Epididymal Fluid: II Interaction of pH and a Quiescence Factor. Biology of Reproduction. 1984;30: 926-935.

25. Erold CC, Butler WR. Reduction of fertility and alteration of uterine $\mathrm{pH}$ in heifers fed excess ruminally degradable protein. Journal of Animal Science. 1993;71: 694-701.

26. Jones JM, Bavister BD. Acidification of Intracellular pH in Bovine Spermatozoa Suppresses Motility and Extends Viable Life. Journal of Andrology. 2000; 21(5):616-624.

27. Sá Filho MF, Ayres H, Ferreira RM, Nichi M, Fosado M, Campos Filho EP, Baruselli PS. Strategies to improve pregnancy per insemination using sex-sorted semen in dairy heifers detected in estrus. Theriogenology. 2010;74:1636-1642.

28. Borsato EA, Ludwig HEJR, Rubin KCP, Saut JPE, Barreiros TRR, Seneda MM, Relationship between the size of the ovulatory follicle and conception rate in Bos taurus x Bos indicus heifers undergoing fixedtime artificial insemination. Revista Brasileira de Reprodução Animal. 2004;28(3):137-142.

29. Vasconcelos JL. M, Sartori R, Oliveira HN, Guinther JG, Wiltbank MC. Reduction in size of the ovulatory follicle reduces subsequent luteal size and pregnancy rate. Theriogenology. 2001;56: 307-314.

30. Mann GE, Lamming GE. Relationship between maternal endocrine environment, early embryo development and inhibition of the luteolytic mechanism in cows. Reproduction. 2001:121:175-180. 